\title{
ORIGINAL ARTICLE \\ Effects of Pesticides-Laden Fruits and Vegetables on the Permeability of Renal \\ Basement Membranes-A Route to Proteinuria
}

Lubna Shahper ${ }^{1}$, Muhammad Qasim Muneer ${ }^{2}$, Sadia Hassan ${ }^{3}$, Nazia Ayyub ${ }^{4}$, Tahir Rasool ${ }^{5}$

\begin{abstract}
Objective: To study the hazardous effects of pesticide residue-laden fruits and vegetables on the permeability of renal basement membrane at proximal and distal convoluted tubules in rats.

Study Design: Observational study.

Place and Duration of Study: The study was conducted at the animal house at the Postgraduate Medical Institute (PGMI), Lahore for 21 consecutive days from $15^{\text {th }}$ Nov 2018 to $6^{\text {th }}$ Dec 2018.

Materials and Methods: The study design was comparative comprising of twelve Wistar male rats. The subjects were divided into two equal groups, control (group A) and experimental (group B). Body weight of subjects were noted before and after the experiment. Triazophos was given to the group B in a dose of $8.2 \mathrm{mg} / \mathrm{kg}$ body weight-sub chronic dose $\left(1 / 10^{\text {th }}\right.$ of LD50) as 1:100 dilution solution by oral gavage for 21 consecutive days. Blood for serum creatinine and 24-hour urine for proteinuria were collected on day 1, 7, 14 and 21 . On day 22, the subjects were sacrificed, kidneys dissected out and preserved in $10 \%$ neutral buffered formalin (NBF) for histological examination. Pre and post experiment body weight of control group was compared with experimental group.
\end{abstract}

Results: The histopathology of the renal basement membrane of group A showed continuity while group B showed interruption, vacuolization, inflammatory cell infiltration and blood vessel congestion in tissues. Biochemical analysis confirmed raised serum creatinine and proteinuria levels.

Conclusion: The pesticide residue-laden fruits and vegetables adversely affect the histology of basement membranes in proximal and distal convoluted tubules leading to disturbed renal functions. The presence of residual pesticides in the food chain is hazardous to human health.

\section{Key Words: Basement Membrane Damage, Pesticides, Proteinuria.}

How to cite this: Shahper L, Muneer MQ, Hassan S, Ayyub N, Rasool T. Effects of Pesticides-Laden Fruits and Vegetables on the Permeability of Renal Basement Membranes-A Route to Proteinuria. Life and Science. 2020; 1(3): 114-118.

doi: http://doi.org/10.37185/LnS.1.1.84

This is an Open Access article distributed under the terms of the Creative Commons Attribution License (http://creativecommons.org/licenses/by/4.0), which permits unrestricted use, distribution, and reproduction in any medium, provided the original work is properly cited.

${ }^{1}$ Department of Anatomy

Postgraduate Medical Institute

Ameer-ud-Din Medical College, Lahore

${ }^{2}$ Department of Anatomy

Allama lqbal Medical College, Lahore

${ }^{3}$ Department of Anatomy

Services Institute of Medical Sciences (SIMS), Lahore

${ }^{4}$ Department of Obs/Gyn

Lahore General Hospital (LGH), Lahore

${ }^{5}$ Akhuwwat Medical Unit

Diabetic Clinic, Lahore

Correspondence:

Dr. Lubna Shahper

Department of Anatomy

Postgraduate Medical Institute

Ameer-ud-Din Medical College, Lahore

E-mail: Ishahper@gmail.com

Funding Source: NIL; Conflict of Interest: NIL

Received: Dec 14, 2019; Revised: Apr 24, 2020

Accepted: Jun 24, 2020

\section{Introduction}

The harmful effect of pesticides extends beyond the target of controlling pests. It involves the non-target spectrum as well. ${ }^{1}$ This has been proven by a number of investigations. ${ }^{2}$ In spite of the scientists' claim that organophosphorus pesticides do not tend to persist or bio accumulate in the environment, pesticide residue is regularly detected in food at low levels, in a range of food items. ${ }^{3}$ High levels have also been detected in human blood. ${ }^{4}$ Crops grown in pesticidecontaminated soil, were detected to contain dangerous levels of pesticide residue, even years after cessation of pesticide application. ${ }^{5}$ Many attempts for restoration of agricultural soil have been tried in vain. ${ }^{6}$ Several methods have been used for the detection of triazophos residue in fruits and 
vegetables, ${ }^{7}$ including immunoassay techniques. ${ }^{8}$ It is hard to render fruits and vegetables free of pesticide residue even after washing them vigorously. ${ }^{9}$ A study was conducted to see the effects of household processing of vegetables and rice, like washing with tap water, salt water washing, lukewarm water washing, open pan cooking and microwave cooking. It was observed that these methods reduced some amount of pesticide residue in the vegetables but did not completely remove them. ${ }^{10}$

In chronic exposure to triazophos, there is release of hazardous free radicals or reactive oxygen species $(\mathrm{ROS})^{11}$ leading to oxidative stress and lipid peroxidation of the renal basement membranes. As a result, there are permeability changes and disturbed renal functions. ${ }^{12}$

The objective of the study is to observe the hazardous effects of pesticide residue-laden fruits and vegetables on the permeability of renal basement membrane at proximal and distal convoluted tubules in rats.

\section{Materials and Methods}

Sampling and procurement of experimental animals: The study was a comparative design. Simple random sampling was adopted for a sample size of twelve. A table of random numbers were produced by Stat Trek's Random Number Generator with the maximum and minimum values of random numbers. Twelve, healthy, male, Wistar rats, aged 6-8 weeks, weighing $175-200 \mathrm{~g}$ were purchased. The permission for the study was obtained from the ethical committee, PGMI, Lahore. The animals were acclimatized for a week. Food and water were made available ad libitum along with maintenance of 12/12-hours light and dark cycle, 50-55\% humidity and $25-30^{\circ} \mathrm{C}$ temperature. The animals were divided into two groups and weighed before and after the experiment. Group A was kept as control and group B as experimental. Group B was given triazophos in a subchronic dose of $8.2 \mathrm{mg} / \mathrm{kg}$ body weight(equivalent to $1 / 10^{\text {th }}$ of LD50) ${ }^{13}$ as $1: 100$ dilution solution by oral gavage while group $A$ was fed on distilled water by oral gavage for 21 consecutive days. ${ }^{14}$

Collection of blood samples: Blood samples were collected from the tails of rats (lateral tail veins) ${ }^{15}$ for serum creatinine ${ }^{16}$ on day $1,7,14$ and 21 ; the last blood sample was drawn through cardiac puncture on day 22 after anesthesia and before their sacrifice. ${ }^{17}$ The blood drawn was immediately shifted to the vacutainer tubes, kept in the test tube stand for about an hour before centrifuging it for obtaining clear serum which was then transferred to sterilized disposable Eppendorf tubes to be analyzed for serum creatinine later.

Collection of 24-hr urine samples: Each animal, was kept in individual metabolic cages on day 1 , day 7 , day 14 and day 21 for the collection of 24 hours-urine samples to measure the proteinuria/24 hours. ${ }^{18}$ The metabolic cages were set up such that there was free access to water and rat feed and below each cage was arrangement for collection of 24-hour urine in graduated beakers each covered with cling film to avoid mixing of feces or dirt particles. The urine collected from the beakers, was shifted into clear sterilized test tubes and their exact quantity measured in milliliters. Proteins $/ \mathrm{ml}$ in the urine were measured with the help of commercially available kit and result multiplied by total quantity of urine in 24 hours.

On day 22, 24-hours after administration of last dose, the rats were sacrificed and their kidneys preserved for histological examination. ${ }^{19}$ Periodic acid-Schiff (PAS) staining was used $^{20}$ as renal tissue have glycoproteins and are strongly PAS positive.

For statistical analysis, Fisher's exact test was applied for qualitative analysis and independent sample ttest for comparison of means of the two groups.

\section{Results}

Body weight of animals before and after the experiment: Body weight of animals in group B before and after the experiment was compared with the before and after body weight of animals in the control group A. No difference in normal weight gain was seen in triazophos-treated group.

Basement membrane interruption at proximal convoluted tubules (PCT): There was statistically significant difference between basement membrane

\begin{tabular}{lccc}
\hline $\begin{array}{l}\text { Table } \\
\text { (PCT) between the groups }\end{array}$ & & \\
\hline BM int & Group A n (\%) & Group B n (\%) & p-value \\
Intact & $6(100.0)$ & $1(16.7)$ & \\
Interrupted & $0(0.0)$ & $5(83.3)$ & $0.015^{*}$ \\
\hline
\end{tabular}

Fisher's exact test

${ }^{*} p$ value $\leq 0.05$ is considered significant 
interruption at PCT between the groups ( $p=0.015)$. Basement membrane PCT of all rats in group A was intact (Fig. 1). In group B, 5 (83.3\%) rats had interrupted basement membrane (Table. 1; Fig. 2, 3, 4).

Basement membrane interruption at distal convoluted tubules (DCT): There was statistically significant difference between interruption of basement membrane at DCT between the two groups ( $p=0.002)$. Basement membrane of DCT in all rats of group A was intact (Table.2; Fig. 1). In group B, all rats had interrupted basement membrane (Table. 2; Fig. 2, 3, 4).

\begin{tabular}{lccc}
\hline \multicolumn{4}{l}{ Table 2: Distribution of basement membrane interruption } \\
\multicolumn{4}{l}{ (DCT) between the groups } \\
\hline BM interruption & $\begin{array}{c}\text { Group A n } \\
\text { (\%) }\end{array}$ & $\begin{array}{c}\text { Group B n } \\
\text { (DCT) }\end{array}$ & p-value \\
Intact & $6(100.0)$ & $0(0.0)$ & \\
Interrupted & $0(0.0)$ & $6(100.0)$ & $0.002^{*}$ \\
\hline
\end{tabular}

Fisher's exact test

${ }^{*} p$ value $\leq 0.05$ is considered statistically significant

Serum creatinine $(\mathrm{mg} / \mathrm{dl})$ : The mean serum creatinine $\mathrm{mg} / \mathrm{dl}$ among groups was compared at day $1,7,14$ and 21 . There was no difference among the groups at day 1 ( $p$-value $=0.601$ ) but there was a statistically significant difference between mean serum creatinine $\mathrm{mg} / \mathrm{dl}$ levels $(p=0.003,0.001$ and 0.001 ) between groups on days 7, 14 and 21 respectively (Table 3 ).

\begin{tabular}{|c|c|c|c|}
\hline $\begin{array}{l}\text { Serum Creatinine } \\
\mathrm{mg} / \mathrm{dl}\end{array}$ & $\begin{array}{l}\text { Group A } \\
\text { Mean } \pm S D\end{array}$ & $\begin{array}{l}\text { Group B } \\
\text { Mean } \pm S D\end{array}$ & p-value \\
\hline Day 1 & $0.677 \pm 0.036$ & $\begin{array}{l}0.660 \pm \\
0.035\end{array}$ & 0.437 \\
\hline Day 7 & $0.685 \pm 0.039$ & $\begin{array}{l}1.170 \pm \\
0.242\end{array}$ & $0.003^{*}$ \\
\hline Day 14 & $0.697 \pm 0.042$ & $\begin{array}{l}1.795 \pm \\
0.180\end{array}$ & $<0.001^{*}$ \\
\hline Day 21 & $0.710 \pm 0.035$ & $\begin{array}{l}2.183 \pm \\
0.367\end{array}$ & $<0.001^{*}$ \\
\hline
\end{tabular}

Independent sample t-test

${ }^{*} p$ value $\leq 0.05$ is considered statistically significant

24-hour Proteinuria (mg/dl): The mean 24-hour proteinuria $\mathrm{mg} / \mathrm{dl}$ was compared among groups at day $1,7,14$ and 21 . There was statistically significant difference between the mean 24-hour proteinuria $\mathrm{mg} / \mathrm{dl}$ levels ( $p=0.002,0.001$ and 0.001 ) between the groups on days 7,14 and 21 respectively (Table 4 ).

\section{Discussion}

In our study, there was statistically significant

\begin{tabular}{|c|c|c|c|}
\hline $\begin{array}{l}\text { 24-hour } \\
\text { Proteinuria } \\
\mathrm{mg} / \mathrm{dl}\end{array}$ & $\begin{array}{l}\text { Group A } \\
\text { Mean } \pm S D\end{array}$ & $\begin{array}{l}\text { Group B } \\
\text { Mean } \pm \text { SD }\end{array}$ & p-value \\
\hline Day 1 & $277.8 \pm 35.9$ & $299.5 \pm 13.8$ & 0.213 \\
\hline Day 7 & $278.3 \pm 36.0$ & $363.0 \pm 34.8$ & $0.002 *$ \\
\hline Day 14 & $279.3 \pm 39.1$ & $444.7 \pm 28.2$ & $<0.001^{*}$ \\
\hline Day 21 & $275.3 \pm 5.2$ & $525.8 \pm 40.6$ & $<0.001^{*}$ \\
\hline
\end{tabular}

Independent sample t-test

${ }^{*} p$ value $\leq 0.05$ is considered statistically significant

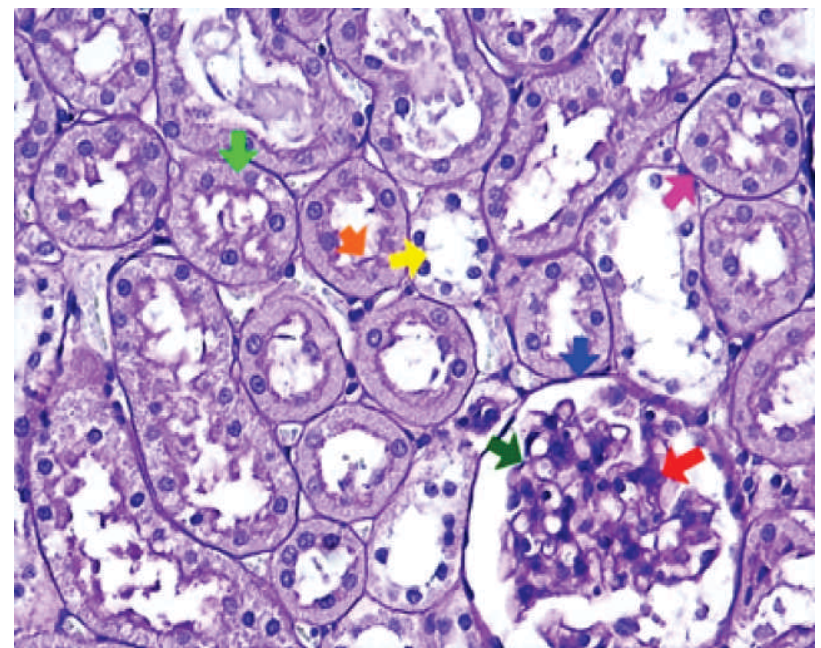

Fig 1: Photomicrograph of group A kidney cortex on day 22 showing glomerulus (red), parietal (blue) and visceral layer (dark-green) of Bowman's capsule; distal tubules (yellow); intact basement membranes (pink); proximal tubule (light-green) with intact brush border (orange). PAS stain X400

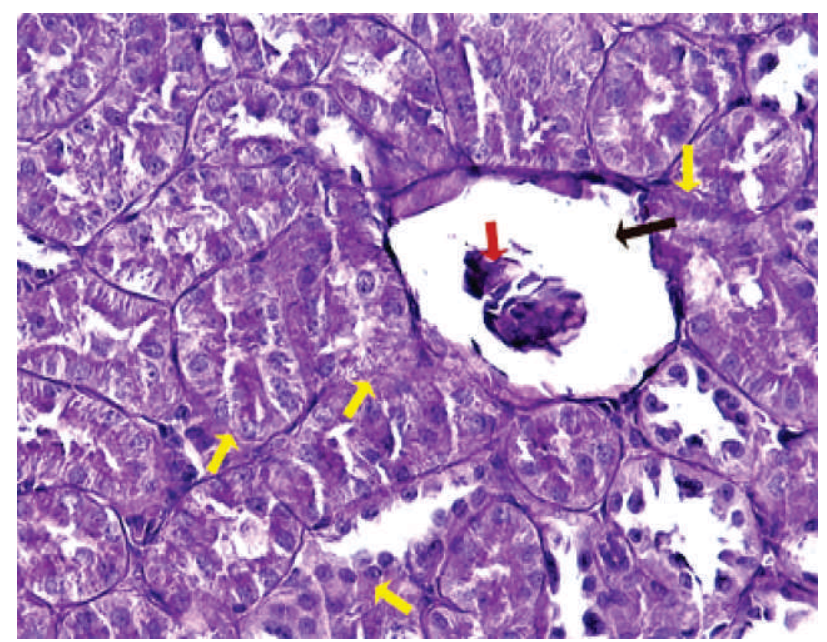

Fig 2: Photomicrograph of group B kidney cortex on day 22 showing glomerulus (red) and apparently widened Bowman's space (black), tubular basement membranes disruption (yellow). PAS stain X400 


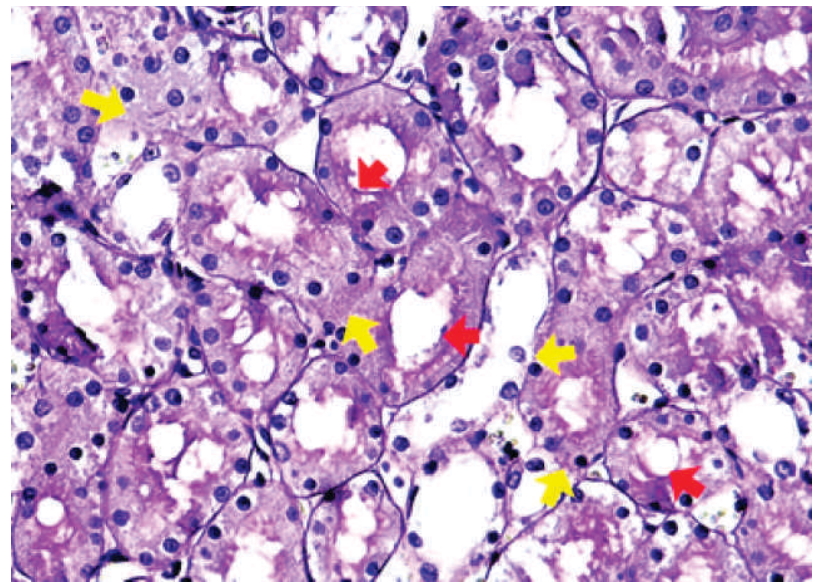

Fig 3: Photomicrograph of cortex of kidney from group B on day 22 showing disruption of tubular basement membranes (yellow) and loss of brush border (red) from proximal convoluted tubule. PAS stain X400

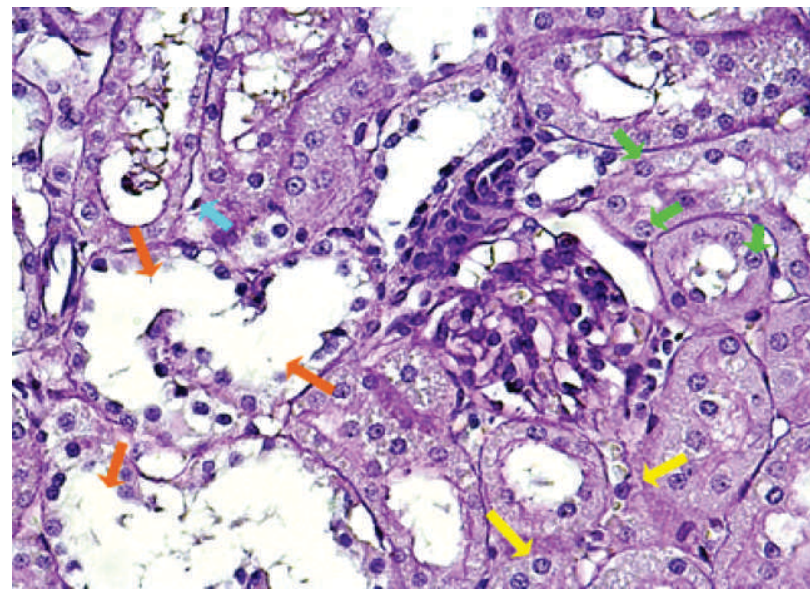

Fig 4: Photomicrograph of cortex of kidney from group B on day 22 showing disrupting and desquamating tubules (orange) due to interrupted basement membrane (yellow), pyknotic nuclei (aqua-blue) and karyorrhexis (light-green) PAS stain X400

interruption of basement membranes at PCT and DCT in the group B ( $p$ value $<0.015$ and 0.002 respectively), where five rats (83.3\%) had interrupted basement membranes (Table 1; Fig. 2, 3, 4). High concentration of ROS released causes lipid peroxidation, thus increasing oxidative stress and disruption of basement membranes. This was also observed by Khan et al. in a study on lead-induced nephrotoxicity. ${ }^{21}$ In group B, degenerated microvilli, loss of brush borders of PCT was seen (Fig. 3). This was reported by Rahman and Sattar study. ${ }^{22}$ The differences in mean serum creatinine $\mathrm{mg} / \mathrm{dl}$ levels were statistically significant among the groups on days 7, 14 and 21 (Table 3). The imbalance and deterioration in the renal function leads to raised serum creatinine levels suggesting tubular insufficiency and impaired glomerular function. ${ }^{22}$

The differences in mean proteinuria $\mathrm{mg} / \mathrm{dl}$ levels were statistically significant among the groups on days 7, 14 and 21 (Table 4). The same was demonstrated by Ghaffar et al. ${ }^{23}$ Male Wistar rats demonstrate a strikingly physiological proteinuria during their sexual maturation (6-10 weeks of age) because of the elevated hydraulic glomerular membrane permeability exclusively for sex-related proteins without significant change in the permeability for other determinants, as compared to the female rats as was observed and proved by Alt et al in $1980 .^{24}$ These low-molecular weight urinary proteins are synthesized in liver, concentrated in the kidneys and excreted with the urine. They are sex dependent and are absent in female urine This urinary protein excretion pattern in the male rats, disappears after castration and during senility. Triazophos has no interaction with the secretion of sex hormones. The subjects of this study were male rats because of this physiological phenomenon. An experimental pathological proteinuria can easily be demonstrated in the male rats, and the level of proteins excreted being above the value of physiological proteinuria in 24-hours. The limitation of this study is small sample size.

\section{Conclusion}

The pesticide residue- on fruits and vegetables adversely affect the histology of renal basement membranes at PCT and DCT and lead to disturbed renal functions of raised serum creatinine and proteinuria in rats The results of the study indicates that the persistence of pesticides residue in the environment and food chain are most likely hazardous to human health.

\section{REFERENCES}

1. Damalas CA, Eleftherohorinos IG. Pesticide exposure, safety issues, and risk assessment indicators. Int. J. Environ. Res. Pub. Health. 2011; 8: 1402-19.

2. Kim KH, Kabir E, Jahan SA. Exposure to pesticides and the associated human health effects. Sci. Total Environ. 2017; 575: 525-35.

3. Hayat K, Afzal M, Aqueel MA, Khan QM. Determination of insecticide residues in fruits, vegetables, pollen, nectar and ground water of Punjab. Pak. J. Agric. Res. (03681157). 2018; 56.

4. Saeed MF, Shaheen M, Ahmad I, Zakir A, Nadeem M, Chistti $A A$, et al. Pesticide exposure in the local community of 
Vehari District in Pakistan: An assessment of knowledge and residues in human blood. Sc. Total Environ. 2017; 587: 13744.

5. Farhan M, Butt ZA, Khan AU, Wahid A, Ahmad M, Kanwal A. Restoration of pesticide contaminated agricultural soil through bio-augmentation and its kinetics. Pak. J. Agric. Sci. 2017; 54.

6. Anwar T, Ahmad I, Tahir S. Determination of pesticide residues in soil of Nawabshah District, Sindh, Pakistan. Pak. J.Zool. 2012; 44.

7. Syed JH, Alamdar A, Mohammad A, Ahad K, Shabir Z, Ahmed $\mathrm{H}$, et al. Pesticide residues in fruits and vegetables from Pakistan: a review of the occurrence and associated human health risks. Environ. Sci. Pollut. Res. 2014; 21: 13367-93.

8. Du $P$, Jin $M$, Zhang $C$, Chen $G$, Cui $X$, Zhang $Y$, et al. Highly sensitive detection of triazophos pesticide using a novel bio-bar-code amplification competitive immunoassay in a micro well plate-based platform. Sensors and Actuators B: Chemical. 2018; 256: 457-64.

9. Brar GS, Patyal SK, Banshtu T. Persistence of Acephate, Profenofos and Triazophos residues in brinjal fruits and soil. The Bioscan. 2017; 12: 33-7.

10. Shakoori A, Yazdanpanah $H$, Kobarfard F, Shojaee $M H$, Salamzadeh J. The Effects of House Cooking Process on Residue Concentrations of 41 Multi-Class Pesticides in Rice. Iran. J. Pharma. Res. IJPR. 2018; 17: 571.

11. Rathod GB, Parmar P, Rathod S, Parikh A. Hazards of free radicals in various aspects of health-a review. J Forensic Toxicol Pharmacol. 2014; 3:1-7.

12. Sharma D, Sangha GK. Triazophos induced oxidative stress and histomorphological changes in liver and kidney of female albino rats. Pestic. Biochem. Physiol. 2014; 110: 7180.

13. Chandra MO, Raj JA, Dogra TD, Rajvanshi AC, Raina AN. Determination of median lethal dose of triazophos with DMSO in wistar rats. Asian J Pharm Clin Res. 2014; 7: 64-7.

14. Jain S, Mythily S, Ahmed RS, Arora VK, Banerjee BD. Induction of oxidative stress and histopathological changes by sub-chronic doses of triazophos. Ind. J. Biochem. Biophy. 2010; 47: 388-92.

15. Lee $G$, Goosens KA. Sampling blood from the lateral tail vein of the rat. J. Vis. Exp. (JoVE). 2015; 18: 52766.

16. Castro BB, Colugnati FA, Cenedeze MA, Suassuna PG, Pinheiro HS. Standardization of renal function evaluation in Wistar rats (Rattus norvegicus) from the Federal University of Juiz de Fora's colony. Brazil. J. Nephrol. 2014; 36: 139-49.

17. Doeing DC, Borowicz JL, Crockett ET. Gender dimorphism in differential peripheral blood leukocyte counts in mice using cardiac, tail, foot, and saphenous vein puncture methods. BMC clinical pathol. 2003; 3:3.

18. Remuzzi A, Puntorieri S, Mazzoleni A, Remuzzi G. Sex related differences in glomerular ultrafiltration and proteinuria in Munich-Wistar rats. Kidney int. 1988; 34: 481-6.

19. Bancroft JD, Gamble M, editors. Theory and practice of histological techniques. Churchill Livingstone. Elsevier health sciences; 2008.

20. Grizzle WE, Fredenburgh JL, Myers RB. Fixation of tissues. Theory and practice of histological techniques. 2008; 6: 5374.

21. Khan NA, Naqvi AN, Perveen KH, Rafique MU. Lead induced nephrotoxicity with special reference to proximal tubule in albino rats. Pak. J. Pharmacol. 2008; 25: 29-35.

22. Rahman SA, Sattar DA. Effect of Different Concentration of Super Cyren Pesticide on Some Physiological and Histological Traits of Mice After Different Periods of Oral Administration. Iraqi J. Sci. 2018; 58: 2291-300.

23. Ghaffar $A$, Ashraf $S$, Hussain $R$, Hussain $T$, Shafique $M$, Noreen $S$, et al. Clinico-hematological disparities induced by triazophos (organophosphate) in Japanese quail. Pak. Vet. J. 2014; 34: 257-9.

24. Alt JM, Hackbarth H, Deerberg F, Stolte H. Proteinuria in rats in relation to age-dependent renal changes. Laboratory animals. 1980; 14: 95-101 